\title{
BIOMODULATORY EFFECT OF LOW INTENSITY LASER (830 nm.) IN NEURAL CELLS 9L/lacZ
}

Antonieta Marques Caldeira Zabeu ${ }^{1}, *$ (D) https://orcid.org/0000-0003-0138-2250

Isabel Chaves Silva Carvalho ${ }^{2}$, iD https://orcid.org/0000-0001-6466-9836

Cristina Pacheco Soares ${ }^{2}$, (D) https://orcid.org/0000-0002-0572-074X

Newton Soares da Silva ${ }^{1}$, (D) https://orcid.org/0000-0001-6452-9278

${ }^{1}$ Institute of Research and Development- IP\&D, Universidade do Vale do Paraíba, Laboratory of Cell Biology and Tissue, São José dos Campos, SP, Brazil.

${ }^{2}$ Institute of Research and Development - IP\&D, Universidade do Vale do Paraíba, Laboratory Dynamic of Cell Compartments, São José dos Campos, SP, Brazil.

*Corresponding author

Antonieta Marques Caldeira Zabeu.

Institute of Research and Development - IP\&D, Universidade do Vale Paraíba, Laboratory of Tissue and Cell Biology. Av. Shishima Hifumi, 2911, São José dos Campos SP 12.244-000, Brazil.

e-mail address: antonieta@univap.br

Phone/fax + 551239471143

Short Title: Low Intensity Laser in Neural Cells

\begin{abstract}
Background: Currently, research is advancing low intensity laser (LIL) in central nervous system cells to available the benefits of this therapy in neurological disorders, and research seeks to establish the best LIL protocol in biological processes of neuronal tissue with the different energy wavelengths $(\lambda)$, and exposure time (s) and frequency $(\mathrm{Hz})$. The aim of this study is to check the biomodulatory effects of the LIL in neural cell culture.

Methods: Diode laser $\lambda=830 \mathrm{~nm}$, power of $40 \mathrm{~mW}$, continuous mode, applied in the cells lineage $9 \mathrm{~L} / \mathrm{lacZ}$, with energy densities of $0.5,1.5$ and $3.0 \mathrm{~J} / \mathrm{cm} 2$. Analysed 24 hours after irradiation, the results of the cell viability show the difference between the control and treated groups.

Results: In the occurrence of apoptosis, no significant manifestation was observed between the control group compared with the irradiated one $(\mathrm{P}=0.9956)$; there was a significant difference between apoptosis and death by necrosis has been between the control and treated groups $(\mathrm{P}<0.001)$. In the comet assay there was not difference.

Conclusions: With the aim of evaluating whether LIL promotes early activation of programmed cell death, of $9 \mathrm{~L} / \mathrm{lacZ}$ cells, in the proposed parameters of LIL, we observed that promoted an increase in the number of neural cells, highlighting the action of biomodulation; LIL did not promote the activation of apoptosis and did not any indication of DNA deterioration in the comet assay. The results of this study are indicative that the near infrared laser has a positive interaction with neuronal cells.
\end{abstract}

Keywords: cell viability, comet assay; DNA damage; electrophoresis; neural cells; low intensity laser 


\section{Introduction}

Neurological diseases, with different brain damages, degenerative or traumatic injuries, kill 6.8 million people per year, accounting for $12 \%$ of global deaths, according to the World Health Organization, 2017 (WHO). The total number of people with dementia is estimated to reach 82 million by 2030 and 152 million by 2050 . According to Alzheimer's Disease International, 2018 part of this increase in the population with degenerative neurological conditions in developing countries is the result of the improvement health conditions and quality of life in these countries.

Currently, research is advancing low intensity laser (LIL) in central nervous system cells in order to assess the benefits of this therapy in neurological disorders such as Alzheimer's, stroke, ischemia, epilepsy, among others (Oron et al. 2007; Gao et al. 2010; Hashmi et al. 2010; Moreira et al. 2011; Liebert et al. 2014). However, the effective action of the laser on the nerve cell is not yet established. LIL has been described as an alternative treatment of various inflammatory (Anders et al. 2010), degenerative (Hashmi et al. 2010; Shen et al. 2013), tissue repair (Moreira et al. 2011), cell proliferation (Oron et al. 2007) processes, among others, mainly because it is not an invasive technique. It is believed that the interaction of light with cellular mitochondria increases the production of adenosine triphosphate (ATP) and therefore promotes cellular processes (Karu 1999; Karu \& Pyatibrat 2011; Barrett et al. 2013). The limits are not defined; minimum and maximum; energy to be deposited in the cell type that does not adversely affect, for example, causing the promotion of early cell death.

The intense scientific research seeks to establish the best LIL irradiation protocol in biological processes of neuronal tissue, in the face of different energy wavelengths $(\mathrm{J} / \mathrm{s})$, $(\lambda)$, and exposure time (s), frequency modulation $(\mathrm{Hz})$, among other parameters.

Many studies are being developed in in vivo experimental models, however there are few results found in neural and neuronal cell extracts. Therefore, it is hypothesized that low-intensity laser irradiation promotes cell biomodulation with cell cycle promotion and other mechanisms involved in cell viability.

The present work objective is to verify if there is early activation of programmed cell death, apoptosis and if the genetic material suffers any deleterious action by irradiation in $9 \mathrm{~L} / \mathrm{lacZ}$ cell at energy densities of $0.5 \mathrm{~J} / \mathrm{cm}^{2} ; 1.5 \mathrm{~J} / \mathrm{cm}^{2}$ and $3.0 \mathrm{~J} / \mathrm{cm}^{2}$ with infrared diode laser.

2. Materials and Methods

\subsection{Low Intensity Laser}

The equipment laser used in this study was an ArGaAl diode (DMC®) detailed in Table 1. Equipment's power was previously verified against a power meter, brand Low pot Medium Power Thermal Sensors, model 30 (150) A-BB-18 (Ophir Phothonics®), with aperture of $35 \mathrm{~mm}$. The irradiation of the cells occurred 24 hours after plating in darker conditions to avoid interference from other light sources. The laser probe was fixed and kept in contact with the lower face of the plate (Figure 1). The irradiation parameters are described in Table 1. 


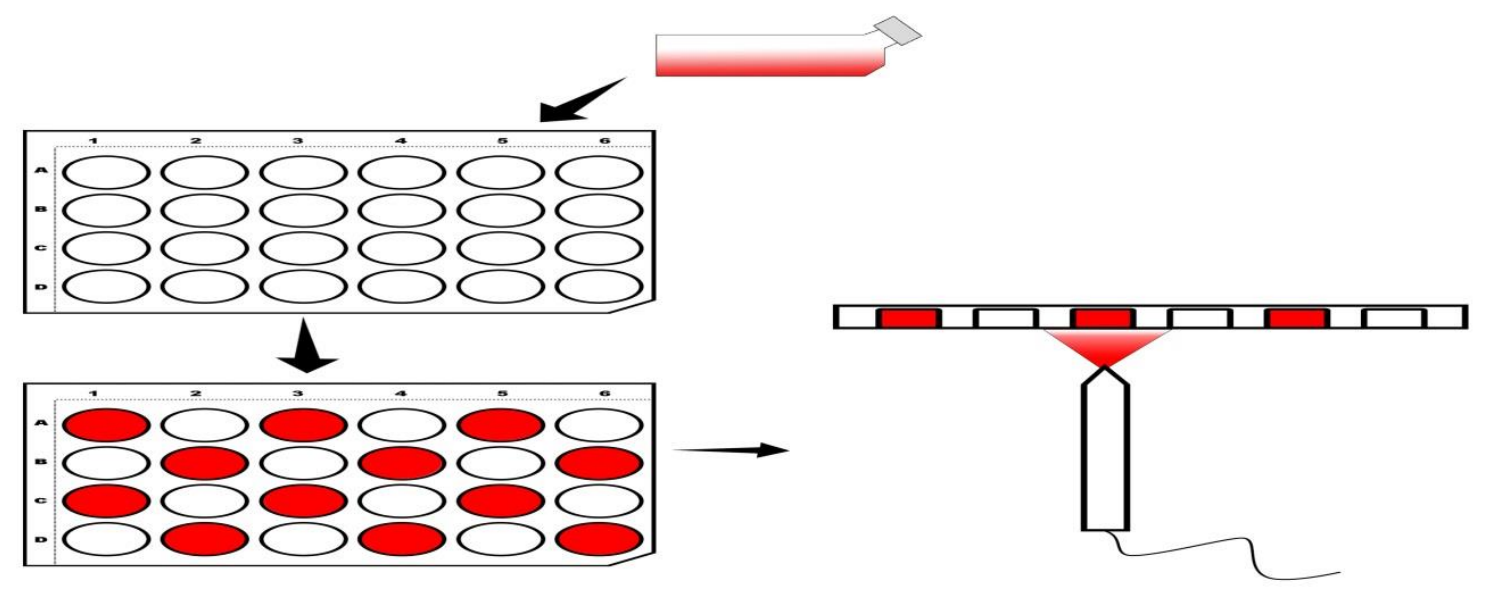

Figure 1. The laser probe was maintained fixed and in contact with the plaque, at the lower surface of the cell container.

Table 1. Specification of the equipment used

\begin{tabular}{|c|c|}
\hline Parameters & Laser \\
\hline$\lambda(\mathrm{nm})$ & 830 \\
\hline$\varnothing(\mathrm{mm})$ & 0.8 \\
\hline $\mathrm{P}(\mathrm{W})$ & 0.04 \\
\hline $\mathrm{A}\left(\mathrm{cm}^{2}\right)$ & 1.93 \\
\hline mode & continuous \\
\hline
\end{tabular}

Caption: $\lambda=$ Wave-length; $\varnothing=$ Fiber diameter; $\mathrm{P}=$ Power; $\mathrm{A}=$ Irradiated area.

\subsection{Cell Culture}

The cells lineage employed in this work is the 9L/lacZ (ATCC® CRL2200TM). The cells were cultured in DMEM high glucose (Sigma-Aldrich Co. LLC) supplemented with $10 \%$ bovine fetal serum and $1 \%$ antibiotics. After a seven day culture in an incubator $\left(\mathrm{CO}_{2}\right.$ Incubator - COM-170AICUV - Panasonic Healthcare) at $37{ }^{\circ} \mathrm{C}, 5 \%$ $\mathrm{CO}_{2}$ enviroment, cells were then trypsinized $(0.25 \%$ trypsin), proceeded to centrifugation (Centrífuga Excelsa Baby I - Fanem - Brasil) at $8000 \mathrm{rpm}$ during 5 min. The cell pellet was resuspended in $2 \mathrm{ml}$ of cell culture medium. An aliquot of the cell suspension was stained with Trypan Blue $(10 \mu \mathrm{L})$, then this portion was transferred to an automatic counter Countess FL II Automated Cell Counter (Thermo Fischer Scientific Inc.). The automatic counter provided the amount of viable cells, and this information was initially adopted as the amount of cells to be placed in each well for irradiation. Cells were cultured in 24-well polystyrene plates with cell density of $1 \times 10^{5}$ cells/well. The culture was maintained in an incubator at $37{ }^{\circ} \mathrm{C}$ and an atmosphere of $5 \% \mathrm{CO}_{2}$ for cell adhesion. Four experimental groups were defined: G1 control group, G2, G3, G4 irradiated groups as described in Table 2. For irradiation, the culture medium was removed and replaced with phosphate 
buffered saline (PBS), avoiding an interference of phenol red staining of the culture medium. At the end of the irradiation, the plate was protected from the action of any other light source. The PBS was replaced by the culture medium and the samples were kept in an incubator at $37{ }^{\circ} \mathrm{C}$ in an atmosphere of $5 \% \mathrm{CO}_{2}$ for 24 hours.

Table 2. Energy deposited in each experimental group

\begin{tabular}{|c|c|c|c|}
\hline Groups & Energy $(\mathrm{J})$ & Energy Density $\left(\mathrm{J} / \mathrm{cm}^{2}\right)$ & Time (s) \\
\hline G1 (control) & 0.0 & 0,0 & 0,0 \\
\hline G2 & 0.9 & 0.5 & 24,12 \\
\hline G3 & 2.7 & 1.5 & 73,5 \\
\hline G4 & 5.4 & 3.0 & 144,75 \\
\hline
\end{tabular}

\subsection{Cell Death - Apoptosis - Annexin V}

To assess whether the laser induced apoptosis in glial cells, Vybrant® Apoptosis Assay Kit Test \# 6 (InvitrogenTM) was used. 24 hours after irradiation, the culture medium was removed and cells were washed with phosphate buffer saline (PBS). The cells were removed with tripsin and centrifuged $8000 \mathrm{rpm}$ for 7 minutes. After centrifugation, the cells were resuspended in $100 \mu \mathrm{l}$ of the staining solution $(25 \mu 1$ of Annexin; $5 \mu \mathrm{L}$ of propidium iodide and $470 \mu \mathrm{L}$ buffer). For quantitative analysis of apoptotic cells the Tali®-based Image Cytometer (Life Technologies Corporation), based on fluorescence assay, was used. The assay result was shown quantitatively in percent of the apoptosis occurrence in a sample of $25 \mu \mathrm{l}$ of $9 \mathrm{~L} / \mathrm{lacZ}$ cells, 24 hours after irradiating with low level laser.

\subsection{Cellular Viability- Violet Crystal}

This assay evaluates the cell density, being reflected by the colorimetric determination of cells stained with crystal violet (CV). After 24 hours of irradiation, the culture medium was discarded from each well, $300 \mu \mathrm{l}$ of staining solution (5\% VC, $1.7 \% \mathrm{NaCl}, 3.3 \%$ paraformaldehyde, ethanol $33,3 \%$ and $56.7 \%$ water) were added to each well and incubated for $5 \mathrm{~min}$ at room temperature. Cells were then washed in sequence and $300 \mu 1$ of DMSO (Dimethylsulfoxide) was added to each well and incubated for a period of 1 hour at room temperature. Absorbance of each sample was determined on an ELISA reader Spectracount (Packard Instrument Company Inc., Meriden, CT, USA) with a $570 \mathrm{~nm}$ filter. The experiment was performed in triplicate (at different times).

\subsection{Comet assay}

Twenty-four hours after irradiation, $200 \mu \mathrm{l}$ of trypsin/0.25\% EDTA (Gibco) were added to each well for 3 min to detach the cells. After centrifugation $(3000 \mathrm{rpm} / 5$ min), each group of cells was resuspended in $200 \mu$ of $0.5 \%$ low-melting point agarose (Gibco) and transferred to slides prepared with $1.5 \%$ agarose (Gibco). The slides were immersed in cold $\left(4^{\circ} \mathrm{C}\right)$ lysis solution $(\mathrm{NaCl} 2.5 \mathrm{M}$, EDTA $100 \mathrm{mM}$, Tris $10 \mathrm{mM} / 1 \%$ Triton $\mathrm{X}-100,10 \% \mathrm{DMSO}$ ) and kept at $4{ }^{\circ} \mathrm{C}$ for $1 \mathrm{~h}$. The prepared slides were placed in a horizontal electrophoresis cube, which was then completed 
with freshly made alkaline buffer at $4{ }^{\circ} \mathrm{C}(300 \mathrm{mM} \mathrm{NaOH}$ and $1 \mathrm{mM}$ EDTA, $\mathrm{pH}$ 13). Electrophoresis was performed at $300 \mathrm{~mA}$ and $25 \mathrm{~V}$ for $30 \mathrm{~min}$. The slides were removed, washed three times ( $5 \mathrm{~min}$ each) with $0.4 \mathrm{M}$ TRIS- $\mathrm{HCl}, \mathrm{pH} 7.5 .30 \mu \mathrm{l}$ of ethidium bromide $(20 \mu \mathrm{g} / \mathrm{mL})$ were added to stain the slides, and the observations were made with a fluorescence microscope Leica DMLB and images will be captures via video camera digital Leica DFC 300FX at $200 \mathrm{X}$ magnification. Thirty randomly selected fields were photographed and analysis was performed on 250 randomly selected cells per group (Lovell et al. 2008). The images were analyzed in the OpenComet software program, in accord with the comet assay protocol was performed by Carvalho et al. (2016). All steps of these analyzes were performed without direct light to avoid further damage to the DNA of the cells.

\subsection{Statistical Analysis}

The results were in triplicate, statistically analyzed by GraphPad Prism 6.0 (GraphPad Inc., La Jolla, CA) by ANOVA nonparametric test and Tukey's multiple comparisons test, posttest at 5\% significance level.

\section{Results}

The results of the cell viability test, by staining with violet crystal, showed a significant difference regarding the density of viable cells in the culture tested $(\mathrm{P}<0.001)$ between the control and treated groups, indicating that there was cell proliferation. Among the treated groups, comparing the $0.5 \mathrm{~J} / \mathrm{cm}^{2}$ group to the $3.0 \mathrm{~J} / \mathrm{cm}^{2}$ group, and the $1.5 \mathrm{~J} / \mathrm{cm}^{2}$ group to the $3.0 \mathrm{~J} / \mathrm{cm}^{2}$ group, the difference was highly significant ( $\mathrm{P}<0.001$ ). However, when comparing the $0.5 \mathrm{~J} / \mathrm{cm}^{2}$ group to $3.0 \mathrm{~J} / \mathrm{cm}^{2}$ group, the statistical difference was lower (Figure 2).

In the evaluation of live, apoptotic and necrotic cells, using the Annex $\mathrm{V}$ assay, the percentage of live cells was considerably high when comparing the groups treated with the control group $(\mathrm{P}<0.001)$. In addition, the statistical results show a difference between the groups treated with $1.5 \mathrm{~J} / \mathrm{cm}^{2}$ and $3.0 \mathrm{~J} / \mathrm{cm}^{2}(\mathrm{P}<0.0093)$. As for the occurrence of apoptosis, also in percentage, no significant manifestation of programmed cell death was observed when the control group was compared with the irradiated groups $(P=0.8894)$, nor in the comparison between the treated groups $(P>0.9999)$. For the evaluation of the percentage of cells killed by necrosis, there was a significant difference in the comparison between the control group and the irradiated groups $(\mathrm{P}<$ 0.001) (Figure 3).

Average tail length and tail time - taken in arbitrary units - and percentage (\%) of DNA in the comet's tail were used in the results of the comet assay evaluation. (Figure 4) There was no significant difference observed between the treated and control groups, $(\mathrm{P}$ $<0.005)$. There was differenced with little significance in the $0.5 \mathrm{~J} / \mathrm{cm}^{2}$ group, compared to $1.5 \mathrm{~J} / \mathrm{cm}^{2}(\mathrm{P}=0.0520)$ in the assessment of\% DNA in the comet's tail. (Figure 3). Thus, the images show the illustration of the cells considered in the Comet assay within the evaluated groups. (Figure 5) 
bioRxiv preprint doi: https://doi org/10.1101/2021.04 08.438993; this version posted May 11, 2021. The copyright holder for this preprint (which was not certified by peer review) is the author/funder, who has granted bioRxiv a license to display the preprint in perpetuity. It is made available under aCC-BY-NC-ND 4.0 International license.

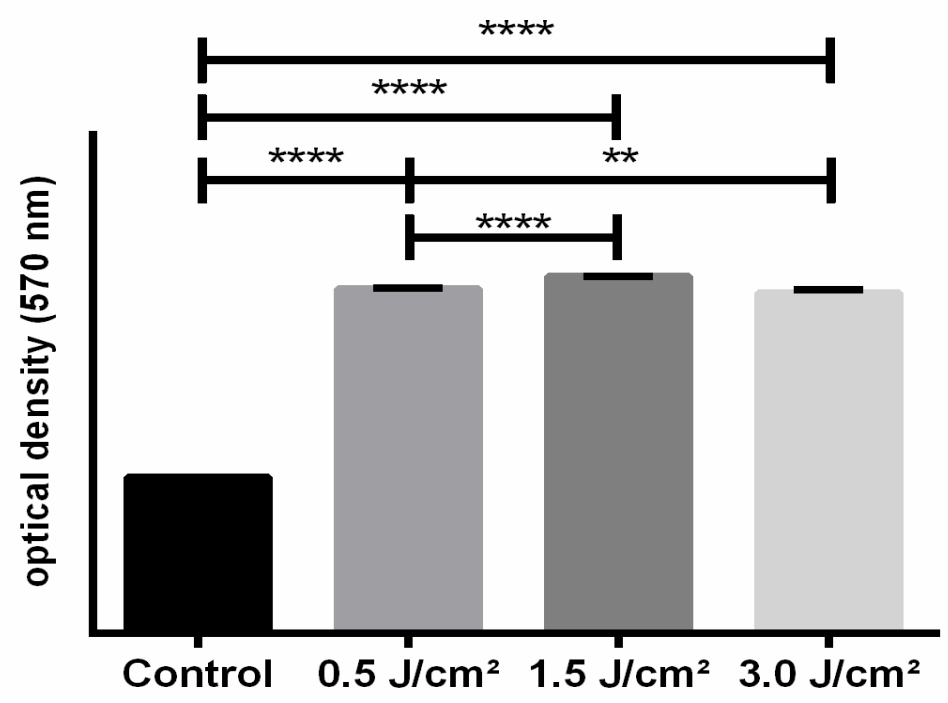

Figure 2 - The graph shows the optical density at $570 \mathrm{~nm}$ of the viable cells by testing the violet crystal. There is significant difference $(P<0.001)$ between control and treated groups among the groups treated by $0.5 \mathrm{~J} / \mathrm{cm}^{2}$ with the group of $3.0 \mathrm{~J} / \mathrm{cm}^{2}$; and comparing groups of $1.5 \mathrm{~J} / \mathrm{cm}^{2}$ and $3.0 \mathrm{~J} / \mathrm{cm}^{2}$, there was also a difference in the optical density of irradiated cells.

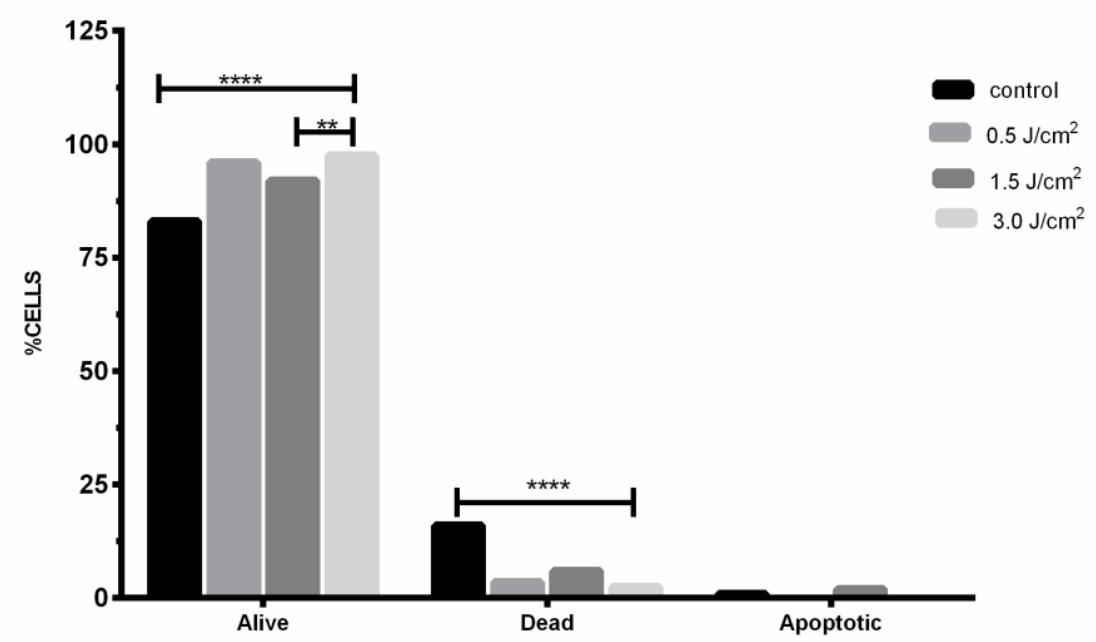

Figure 3 - The graph shows the percentage of living cells, and apoptotic cell death, available by Annexin $V$. The differences were highly significant compared to control treated groups $(P<0.001)$ between the groups treated with $1.5 \mathrm{~J} / \mathrm{cm}^{2}$ and $3.0 \mathrm{~J} / \mathrm{cm}^{2}(P<0.0093)$. In the assessment of cell death by necrosis, when comparing between the control group and the treated group, there was no statistical difference observed $(P<0.001)$. The evaluation of the occurrence of apoptosis between control and treated groups $(P=0.8894)$ and between treatment groups $(P>0.9999)$. 


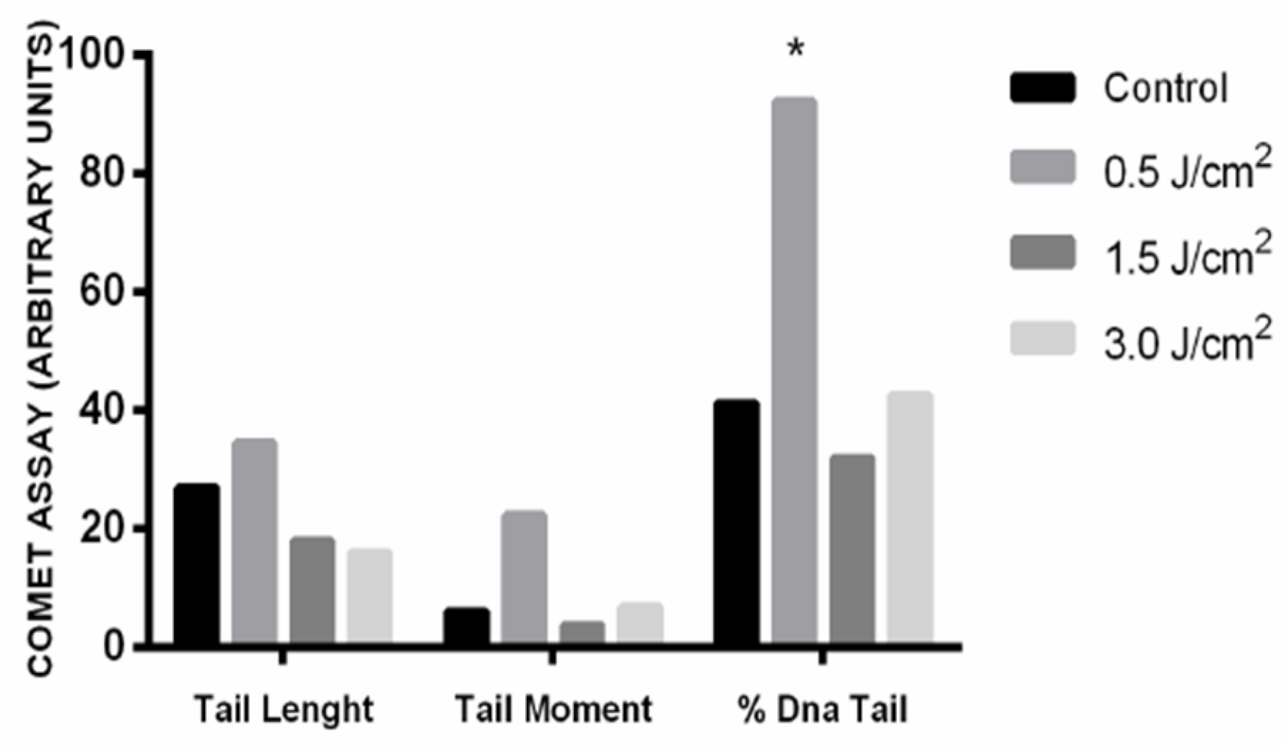

Figure 4 - The graph shows length, moment (in arbitrary units) and \% DNA in the tail of the comet. No significant difference in the comparison between the treated and control groups has been detected, and there was difference with little significance in the $0.5 \mathrm{~J} / \mathrm{cm}^{2}$ group, compared to $1.5 \mathrm{~J} / \mathrm{cm}^{2}(P=0.0520)$ in the \% DNA tail.

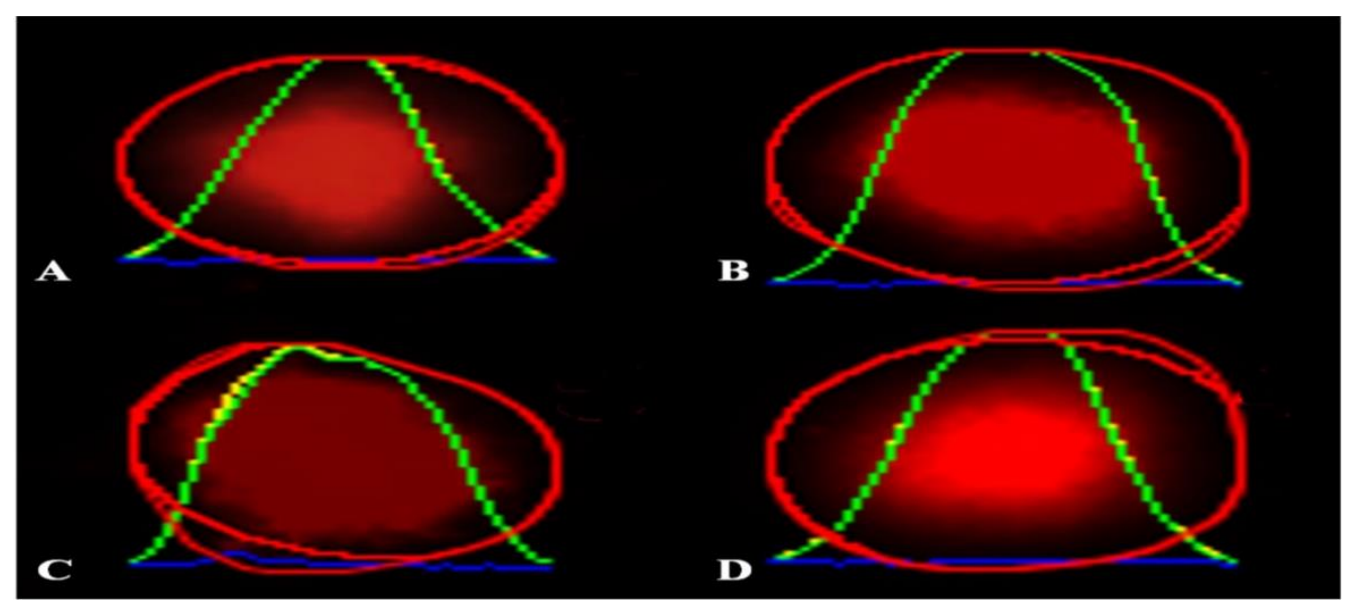

Figure 5 - Illustration of cells considered in the Comet assay: (a) $0.5 \mathrm{~J} / \mathrm{cm}^{2}$, (b) $1.5 \mathrm{~J} / \mathrm{cm}^{2}$, (c) $3.0 \mathrm{~J} / \mathrm{cm}^{2}$, (d) no irradiation.

\section{Discussion}

The energy densities used were selected (Mochizuki-Oda et al. 2002; Giuliani et al. 2009), wavelength ( Oron et al. 2007; Wu et al. 2009) and mode of energy delivery (Wu et al. 2009) in different published studies, using infrared lasers on nerve cells (Von Leden et al. 2013; Murayama et al. 2012). The action of low-power laser in the cell has its mechanism based on the absorption of photon energy by mitochondria cytochrome $\mathrm{C}$ oxidase (Gao et al. 2009; Barrett et al. 2013; Wang et al. 2015). This photon receptor plays an important role in neuronal physiology, acting directly on energy metabolism 
and stimulation of cell signaling pathways; and that this absorption of light by the mitochondrial cytochrome is probably linked to several neuroprotective effects promoted by LIL. In addition, the increase in cellular ATP (adenosine triphosphate) improves the energy support of cells and, consequently, increases cellular processes in general. It has been shown that the increase in adenosine triphosphate is due to the increase in extracellular ATP for dermal cells when irradiated at $657 \mathrm{~nm}$, continuous 35 $\mathrm{mW}, 0.28 \mathrm{~W} / \mathrm{cm}^{2}$ at a dose of $17-85 \mathrm{~J} / \mathrm{cm}^{2}$ over time, from 1 to 5 minutes, hat the aforesaid event occurs that laser promotes positive regulation of ATPase (Rojas et al. 2013; Gonzalez-Lima et al. 2014; Barboza et al. 2014).

According to Hamblin et al. 2016, the effects can be divided into three fronts of action, beginning with the immediate effect of increasing ATP and improving cell oxygenation, followed by activation in the regulatory proteins of anti-apoptotic processes and the production of antioxidants substances such as reactive oxygen species (ROS); finally, there is the formation of neurotrophies and neurogenesis, which both act in tissue repair.

The results of the cell viability test, by staining with violet crystal, showed a significant difference $(\mathrm{P}<0.001)$ between the control and the treated groups, regarding cell viability. Among the treated groups, when compared to the $0.5 \mathrm{~J} / \mathrm{cm}^{2}$ group with the 3.0 $\mathrm{J} / \mathrm{cm}^{2}$ group; and comparing groups of $1.5 \mathrm{~J} / \mathrm{cm}^{2}$ and $3.0 \mathrm{~J} / \mathrm{cm}^{2}$, the difference was highly significant. However, when comparing the $0.5 \mathrm{~J} / \mathrm{cm}^{2}$ and $3.0 \mathrm{~J} / \mathrm{cm}^{2}$ groups, the statistical significance was lower (Figure 2). These results clearly show the biomodulator effect of laser therapy in these cells cultures - the maintenance of cell viability is closely linked to the cell's energy production. The photochemical effects promoted by the interaction of light with mitochondrial cytochrome $\mathrm{C}$ and with cellular water triggers a series of biological responses, these being mediated by the production of free radicals that activate cellular mechanisms; as well as an increase in protein synthesis and cytokines that impact cell proliferation (Kim et al. 2011; Barolet et al. 2016; Tsai et al. 2017). The difference between the energy densities of $0.5 \mathrm{~J} / \mathrm{cm}^{2}$ and $3.0 \mathrm{~J} / \mathrm{cm}^{2}$, in which the statistical significance was lower in relation to the other groups tested, corroborates the findings of Lubart et al. 2006, who reports an additional increase in dose of light energy generates a protective antioxidant effect of the cell. Still, Sommer et al. 2012, in their study with neural cells, human neuroblastoma demonstrated that laser prevents oxidative stress and improves mitochondrial efficiency that provides energy for cellular metabolism in general.

Regarding the occurrence of cell death, our study shows a significant difference in the occurrence of death by necrosis when compared to the groups treated with the control ( $\mathrm{P}$ $<0.001$ ) only (Figure 3 ). This result of death by necrosis may be due to the oxidative stress caused to the cell by LIL, although with statistical significance when we look at the graphic expression of this result, it is clear that the amount of necrotic cells in the sample is small in relation to the resulting proliferation and concentration treatment with LBI. Apoptosis death was not significant in any of the treated groups.

These results suggest that LIL promoted cellular processes, characterizing that there was a biomodulatory effect of the tested cell and increased cellular ATP. A next step in our research project will be the quantification of ATP, ATPase in this experimental model 
of the 9L/lacZ cell, in order to confirm the hypothesis that LIL increases the energy contribution of this cell with the consequent promotion of its metabolism.

A study comparing two wavelengths, $830 \mathrm{~nm}$ and $652 \mathrm{~nm}, 4.8 \mathrm{~W} / \mathrm{cm}^{2}$, in continuous mode, directly irradiated in rat brains (Wang et al. 2015) showed significant differences in the increase in ATP in the $830 \mathrm{~nm}$ laser group. Another report (Sharma et al. 2011) using $810 \mathrm{~nm}$, power density of $25 \mathrm{~mW} / \mathrm{cm}^{2}$ at energies of $0.03 ; 0.3 ; 3 ; 10,30 \mathrm{~J} / \mathrm{cm}^{2}$ in continuous mode quantified reactive oxygen species, increased nitric oxide, changes in mitochondrial membrane potential, increased intracellular content of cellular and cellular ATP.

The wavelength used in this study $(830 \mathrm{~nm})$ is selected to be within the infrared spectrum in accordance with the literature search. In addition, infrared experiments reported by Von Leden et al. $2013\left(808 \mathrm{~nm}, 50 \mathrm{~mW}, 0.2,4,10\right.$ and $\left.30 \mathrm{~J} / \mathrm{cm}^{2}\right)$ and Murayama et al. $2012\left(\lambda 808 \mathrm{~nm}, 30 \mathrm{~mW}, 18,36\right.$ and $\left.54 \mathrm{~J} / \mathrm{cm}^{2}\right)$ demonstrated that the interaction of neuronal cells is better at infrared wavelengths. The literature confirms the results found in this study, which used infrared laser, $\lambda 830 \mathrm{~nm}$.

Some authors (Karu 1999; Karu \& Pyatibrat 2011; Sharma et al. 2011) describe that the increase in ATP and HeLa cell cultures increases cell responses depending on the proliferative phase in which the cell is demanding more or less energy consumption. Carnevalli et al. 2003, demonstrated that LIL improves the cell division process, keeping the membrane and the genetic material preserved after irradiation with ovarian epithelium from the $\lambda 830 \mathrm{~nm}, 10 \mathrm{~mW}, 2 \mathrm{~J} / \mathrm{cm}^{2}$ cell culture. In addition, other authors (Von Leden et al. 2013; Sharma et al. 2011; Evans et al. 2009; Yazdani et al. 2012) in their experimental studies showed that results such as cell proliferation depends on fluency, when it is very high promoting an opposite effect of inhibiting cell proliferation. The results obtained (Figure 4) showed that the cells even at a dose of 3.0 $\mathrm{J} / \mathrm{cm}^{2}$, which was the higher dose in this protocol, maintained its entire preserved genetic material by supplementing the information obtained in test Annexin $\mathrm{V}$, described in the preceding paragraphs, where there was no apoptotic death and cell proliferation. These results corroborate the literature and the comments we obtained in the essay of the comet in which we carried out this experiment, as discussed in sequence.

The technique chosen to assess the occurrence of DNA fragmentation in this experiment was electrophoresis in microgel cells, commonly called a comet assay, used to assess DNA damage and cell repair, individually, cell by cell, and consists of lysis of cell membrane, followed by the migration of the DNA released in the agarose matrix. When viewed under fluorescence microscopy, the shape of the cell has the appearance of a comet, where the head is the nuclear region and the tail is the fragments or strands of the damaged DNA. The comet assay is part of the International Organization for Standardization (ISO), number 10993-3- 2014, to assess genotoxicity; it is a test that clearly demonstrates the occurrence of damage to cellular DNA, no doubt. It is a test widely used to investigate the genotoxic potential of highly toxic substances, such as heavy metals, pesticides, anti-tumor drugs, among others (Moller 2018).

In addition, this test is a good tool in the investigation of cell repair, in conjunction with studies of apoptosis and cell necrosis - just as it was done in this study. As already 
discussed in the previous paragraphs, our tests for evaluating the viability of the cells of this experimentation and programmed cell death showed that biomodulation occurred and already signaled the probability that there would be no damage to the genetic material of these cells. Then, our results, in the evaluation of the comet test, showed that the low intensity laser, within this experimental protocol, with the parameters used for this experimental test, did not cause cell DNA fragmentation after 24 hours of contact. The study performed by Kong et al. 2009, in which the different responses of HeLa cells irradiated with different wavelengths, between ultraviolet and near infrared, and which induced lesions directly in the cell nucleus have been analyzed in vitro, has shown that double-stranded DNA disruption can occur at all laser wavelengths, with blue and green lasers causing more aggressive damage to cellular DNA. However, the results of cells irradiated by infrared laser (using sapphire laser at $200 \mathrm{fs}, 800 \mathrm{~nm}$, continuous) showed damage to the genetic material. Nevertheless, they observed that DNA repair was promoted quickly, and the injured area was smaller, without propagation and being sensitive to the detection of the comet test. The authors concluded that damage to cellular DNA is directly dictated by the applied energy, wavelength, duration of irradiation and pulse rate as well as the cellular damage repair mechanism, thus corroborating the results that we could observe in our study. This behavior of the 9L/lacZ cell against low-level laser irradiation is possibly due to the activation of the cell's protection mechanisms, anti-apoptotic proteins and neurotrophins, which are activated by oxidative stress caused by photons, followed by increased mitochondrial membrane potential, increased $\mathrm{O}_{2}$ circulation and cellular metabolism, resulting in greater production of mitochondrial ATP.

Reynolds et al. 2013 reviewed the DNA repair dynamics evaluation studies in detail, in which the induction of cell DNA damage was caused by laser irradiation and the authors demonstrated that both the damage to the cell's genetic material and the repair of that damage are related to the shape of wave used and where the damage occurs in cellular DNA. Cell damage, exogenous or endogenous, when it exceeds the cell's repair capacity, causes cell death or mutations that can be incorporated into the cell genome.

When the neuronal cell undergoes the action of photons from the laser light, an excitatory photophysical effect of the molecules takes place and, that is resulted, photochemical effects occurs, such as increased ROS, leading to mitochondrial signaling that activates cytoprotective mechanisms. Believed, also, that not us observing lesions in the genetic material of the tested cells, since cell repair was effectively activated to treat any disorder that the cells suffered from the action of the challenged LIL sample.

One of the objectives of this study is to evaluate whether, within the laser parameters applied to the $9 \mathrm{~L} / \mathrm{lacZ}$ culture cells, it would lead to any disturbance occurring in the cellular DNA by the comet test. However, in this study, 24 hours after irradiation, in evaluating cells for the occurrence of DNA fragmentation, the results showed that in the energy density in the employed range $\left(0.5,1.5\right.$ and $\left.3.0 \mathrm{~J} / \mathrm{cm}^{2}\right)$; it did not cause any damage to the DNA of glial cells, confirming the results reported in the literature (Kong et al. 2009; Zabeu \& Pacheco-Soares 2015). 
Even so, the analysis of the results suggests the expansion of the studies, through the investigation of greater precision in the in vitro application of the dose of energy supported by the neural cells (DL-50), looking for similarity with the reports of the scientific literature, which apply the LIL in vivo, in order to establish from which power densities, they start to be harmful, as well as an evaluation of the ideal way to supply this energy, in a pulsed or continuous wave.

\section{Conclusion}

Exist a lot of research and clinical use of low intensity laser (LIL) for neurological disease but no protocol specific for each disorder are discuss. In the present study, we hypothesized that the interaction of laser light at energy densities of $0.5,1.5$ and 3.0 $\mathrm{J} / \mathrm{cm}^{2}$ with $9 \mathrm{~L} / \mathrm{lacZ}$ cells could lead to some cellular disorder, such as decreasing cell viability, promoting programmed cell death (apoptosis) or necrotic death; or any imbalance and changes in cellular DNA.

Regarding the objective of evaluating whether LIL promotes early activation of programmed cell death, apoptosis of $9 \mathrm{~L} / \mathrm{lacZ}$ cells at different energy densities of the infrared diode laser, we observed that the use of low-power laser promoted an increase in the number of cells, suggesting that the biomodulatory action of the laser. In addition, LIL did not promote the activation of programmed cell death - apoptosis. The results of this study are indicative that the near infrared laser has a positive interaction with neuronal cells.

6. Ethics approval and consent to participate

This article is not involved in personal information and ethical approval is not required.

\section{Consent for publication}

Not applicable.

8. Availability of data and material

No additional supporting data in this article.

\section{Competing interests}

All the authors declared there is no conflict of interest or ethical concern in this article. 


\section{Funding}

This study was financially supported by Coordination for the Improvement of Higher Education Personnel (CAPES) and grant of São Paulo Research Foundation FAPESP (2016/17984-1 and 2013/20054-8)

\section{Acknowledgements}

We thank Ph.D. Rafael da Cruz Ribeiro Berti - Laboratory of Environmental and Thermal Engineering - USP/Sao Paulo/Brazil for support in laser diode ArGaAl (DMC@) calibration. Ph.D. Clayton Barcelos Zabeu - Mauá Technology Institute - Sao Paulo/Brazil for support in statistical analysis.

\section{Authors' contributions}

AMCZ conceived and designed the experiments, analyzed and interpreted data, performed experiments and wrote the manuscript; ICSC assisted in the performed experiments; CPS analyzed and interpreted data; NSS revised the manuscript and gave the final approval of the version to be published. The author (s) read and approved the final manuscript.

13. Bibliography

1. Alzheimer's Disease International. World Alzheimer Report 2018. The state of the art of dementia research: New frontiers. 2018.

2. Anders J, Moges H, Wu X, Ilev I, Waynant R, Longo L. The combination of light and stem cell therapies: a novel approach in regenerative medicine. In AIP Conference Proceedings (2010;1226(1):3-10). American Institute of Physics.

3. Barboza CAG, Ginani F, Soares DM, Henriques ÁCG, Freitas RDA. Low-level laser irradiation induces in vitro proliferation of mesenchymal stem cells. Einstein (Sao Paulo). 2014; 12 (1):75-81.

4. Barolet D, Christiaens F, Hamblin MR. Infrared and skin: Friend or foe. Journal of Photochemistry and Photobiology B: Biology. 2016; 155:78-85.

5. Barrett DW, Gonzalez-Lima F. Transcranial infrared laser stimulation produces beneficial cognitive and emotional effects in humans. Neuroscience. 2013; 230:13-23.

6. Carnevalli CM, Soares CP, Zângaro RA, Pinheiro AL, Silva NS. Laser light prevents apoptosis on Cho K-1 cell line. Journal of Clinical Laser Medicine and Surgery. 2003; 21 (4):193-196.

7. Carvalho ICS, Dutra TP, De Andrade DP, Balducci I, Pacheco- Soares C, Rocha RFD. High doses of alcohol during pregnancy cause DNA damages in osteoblasts of newborns rats. Birth Defects Research Part A: Clinical and Molecular Teratology. 2016; 106 (2):122-132.

8. Evans DH, Abrahamse H. A review of laboratory-based methods to investigate second messengers in low-level laser therapy (LLLT). Medical Laser Application. 2009; 24(3):201-215. 
9. Gao X, Xing D. Molecular mechanisms of cell proliferation induced by low power laser irradiation. Journal of Biomedical Science. 2009;16(1):4.

10. Giuliani A, Lorenzini L, Gallamini M, Massella A, Giardino L, Calzà L. Low infra-red laser light irradiation on cultured neural cells: effects on mitochondria and cell viability after oxidative stress. BMC Complementary and Alternative Medicine. 2009;9(1):8

11. Gonzalez-Lima F, Barksdale BR, Rojas JC. Mitochondrial respiration as a target for neuroprotection and cognitive enhancement. Biochemical Pharmacology. 2014; 88(4):584-593.

12. Hamblin MR. Shining light on the head: photobiomodulation for brain disorders. BBA Clinical. 2016; 6:113-124.

13. Hashmi JT, Huang YY, Osmani BZ, Sharma SK, Naeser MA, Hamblin MR. Role of low level laser therapy in neurorehabilitation. PM\&R. 2010; 2: S292S305.

14. International Organization for Standardization. ISO 10993-3: 2014. Tests for genotoxicity, carcinogenicity and reproductive toxicity. Biological Evaluation of Medical Devices, 2014.

15. Karu T. Primary and secondary mechanisms of action of visible to near-IR radiation on cells. Journal of Photochemistry and Photobiology B: Biology. 1999; 49(1):1-17.

16. Karu T, Pyatibrat L. Gene expression under laser and light- emitting diodes radiation for modulation of cell adhesion: Possible applications for biotechnology. IUBMB Life. 2011; 63(9):747-753.

17. Karu T, Pyatibrat L, Kalendo G. Irradiation with He-Ne laser increases ATP level in cells cultivated in vitro. Journal of Photochemistry and PhotobiologyBiology Section. 1995; 7(3):219-224.

18. Kim WS, Calderhead RG. Is light-emitting diode phototherapy (LED-LLLT) really effective?. Laser Therapy. 2011; 20(3):205-215.

19. Kong X, Mohanty SK, Stephens J, Heale JT, Gomez-Godinez V, Shi LZ, Berns MW. Comparative analysis of different laser systems to study cellular responses to DNA damage in mammalian cells. Nucleic Acids Research. 2009; 37(9):e68e68.

20. Liebert AD, Bicknell BT, Adams RD. Protein conformational modulation by photons: A mechanism for laser treatment effects. Medical Hypotheses. 2014; 82(3):275-281.

21. Lovell DP, Omori T. Statistical issues in the use of the comet assay. Mutagenesis. 2008; 23(3):171-182.

22. Lubart R, Lavi R, Friedmann H, Rochkind S. Photochemistry and photobiology of light absorption by living cells. Photomedicine and Laser Therapy. 2006; 24(2):179-185.

23. Mochizuki-Oda N, Kataoka Y, Cui Y, Yamada H, Heya M, Awazu K. Effects of near-infra-red laser irradiation on adenosine triphosphate and adenosine diphosphate contents of rat brain tissue. Neuroscience Letters. 2002; 323(3):207210.

24. Moller P. The comet assay: ready for 30 more years. Mutagenesis. 2018; 33(1):1-7. 
25. Moreira MS, Velasco IT, Ferreira LS, Ariga SK, Abatepaulo F, Grinberg LT, Marques MM. Effect of laser phototherapy on wound healing following cerebral ischemia by cryogenic injury. Journal of Photochemistry and Photobiology B: Biology. 2011; 105(3): 207-215.

26. Murayama H, Sadakane K, Yamanoha B, Kogure S. Low-power 808-nm laser irradiation inhibits cell proliferation of a human-derived glioblastoma cell line in vitro. Lasers in Medical Science. 2012; 27(1):87-93.

27. Oron U, Ilic S, De Taboada L, Streeter J. Ga-As $(808 \mathrm{~nm}$ ) laser irradiation enhances ATP production in human neuronal cells in culture. Photomedicine and Laser Surgery. 2007; 25(3):180-182.

28. Reynolds P, Botchway SW, Parker AW, O'Neill P. Spatiotemporal dynamics of DNA repair proteins following laser microbeam induced DNA damage-when is a DSB not a DSB?. Mutation Research/Genetic Toxicology and Environmental Mutagenesis. 2013; 756(1-2):14-20.

29. Rojas JC, Gonzalez-Lima F. Neurological and psychological applications of transcranial lasers and LEDs. Biochemical Pharmacology. 2013; 86(4):447-457.

30. Sharma SK, Kharkwal GB, Sajo M, Huang YY, De Taboada, L, Mccarthy T, Hamblin MR. Dose response effects of $810 \mathrm{~nm}$ laser light on mouse primary cortical neurons. Lasers in Surgery and Medicine. 2011; 43(8):851-859.

31. Shen CC, Yang YC, Chiao MT, Chan SC, Liu BS. Low-level laser stimulation on adipose-tissue-derived stem cell treatments for focal cerebral ischemia in rats. Evidence-Based Complementary and Alternative Medicine, 2013.

32. Sommer AP, Bieschke J, Friedrich RP, Zhu D, Wanker EE, Fecht HJ, Hunstein W. $670 \mathrm{~nm}$ laser light and EGCG complementarily reduce amyloid- $\beta$ aggregates in human neuroblastoma cells: basis for treatment of Alzheimer's disease? Photomedicine and Laser Surgery. 2012; 30(1):54-60.

33. Tsai SR, Hamblin MR. Biological effects and medical applications of infrared radiation. Journal of Photochemistry and Photobiology B: Biology. 2017; 170:197-207.

34. Von Leden RE, Cooney SJ, Ferrara TM, Zhao Y, Dalgard CL, Anders JJ, Byrnes KR. $808 \mathrm{~nm}$ Wavelength Light Induces a Dose Dependent Alteration in Microglial Polarization and Resultant Microglial Induced Neurite Growth. Lasers in Surgery and Medicine. 2013; 45(4):253-263.

35. Wang L, Hu L, Grygorczyk R, Shen X, Schwarz W. Modulation of extracellular ATP content of mast cells and DRG neurons by irradiation: studies on underlying mechanism of low-level-laser therapy. Mediators of Inflammation. 2015.

36. World Health Organization. Global action plan on the public health response to dementia. 2017; 2017-2025.

37. Wu JY, Wang YH, Wang GJ, Ho ML, Wang CZ, Yeh ML, Chen CH. Lowpower GaAlAs laser irradiation promotes the proliferation and osteogenic differentiation of stem cells via IGF1 and BMP2. PloS One. 2012; 7(9):e44027.

38. Wu X, Dmitriev AE, Cardoso MJ, Viers- Costello AG, Borke RC, Streeter J, Anders JJ. $810 \mathrm{~nm}$ Wavelength light: an effective therapy for transected or contused rat spinal cord. Lasers in Surgery and Medicine. 2009; 41(1):36-41.

39. Yazdani SO, Golestaneh AF, Shafiee A, Hafizi M, Omrani HAG, Soleimani M. Effects of low level laser therapy on proliferation and neurotrophic factor gene 
expression of human schwann cells in vitro. Journal of Photochemistry and Photobiology B: Biology. 2012; 107:9-13.

40. Zabeu AMC, Pacheco-Soares C. Action of LLLT (Low Level Laser Therapy) In Cells Culture 9L/lacZ. Advances in Laserology, Selected Papers of Laser Florence 2015 Congress, Medimond Publisher in June 2016 by Editografica Bologna, 2015;73-76. 

sis 


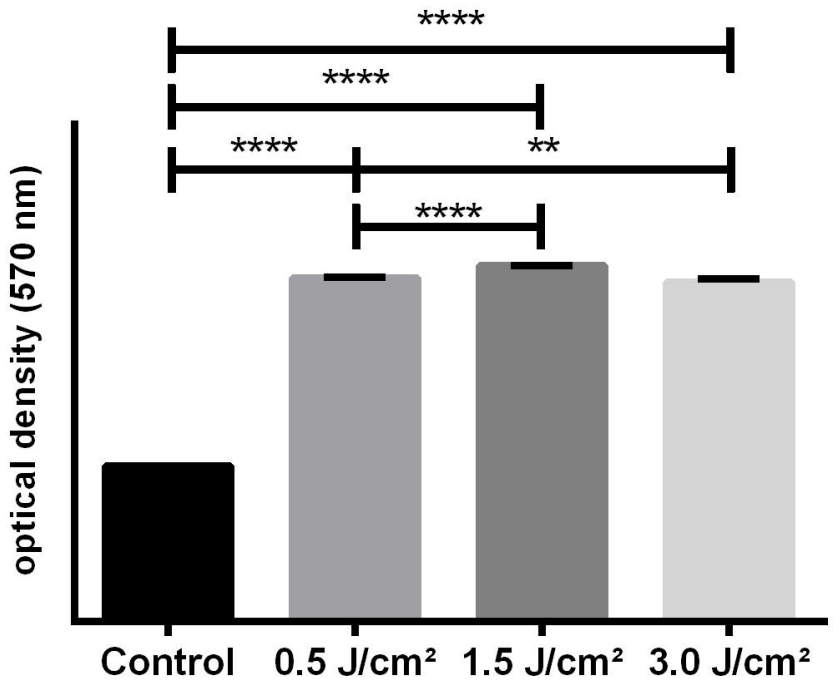




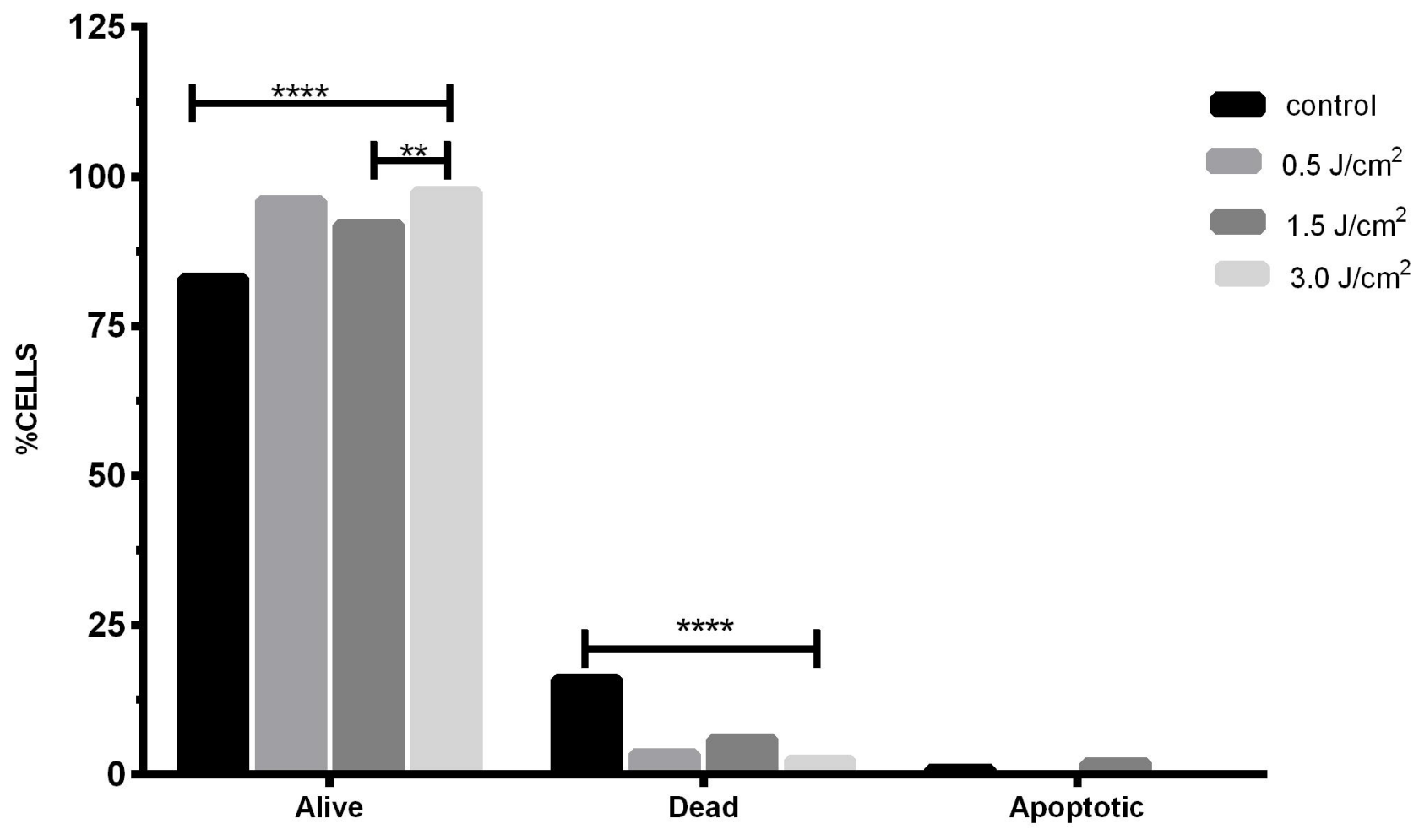




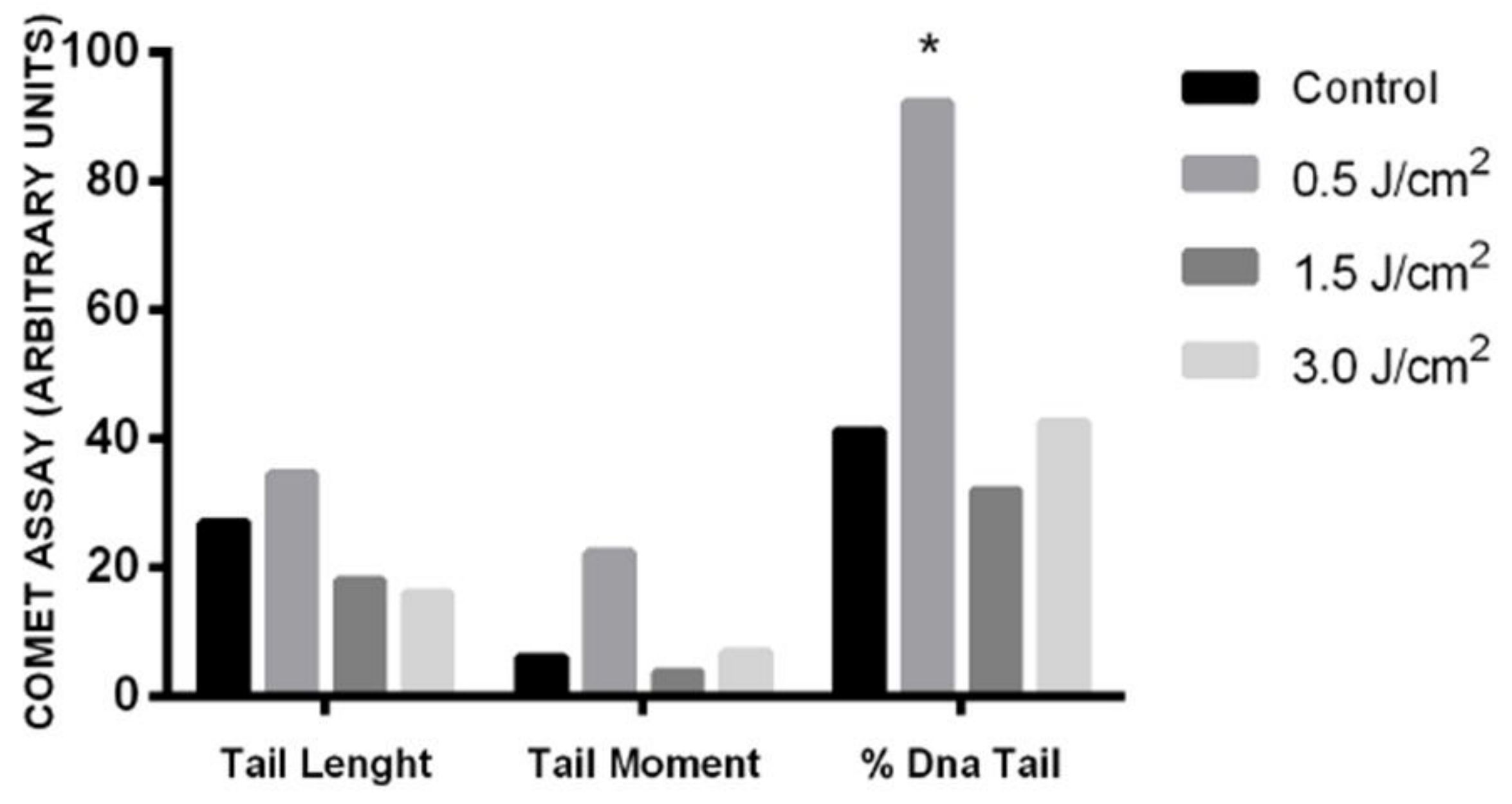


A

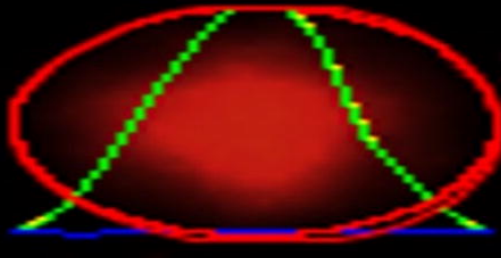

C

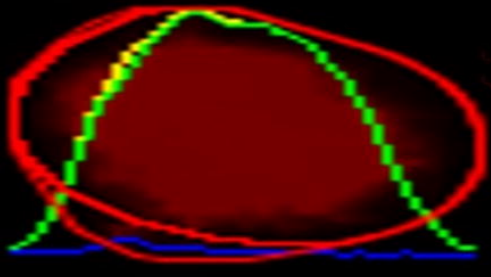

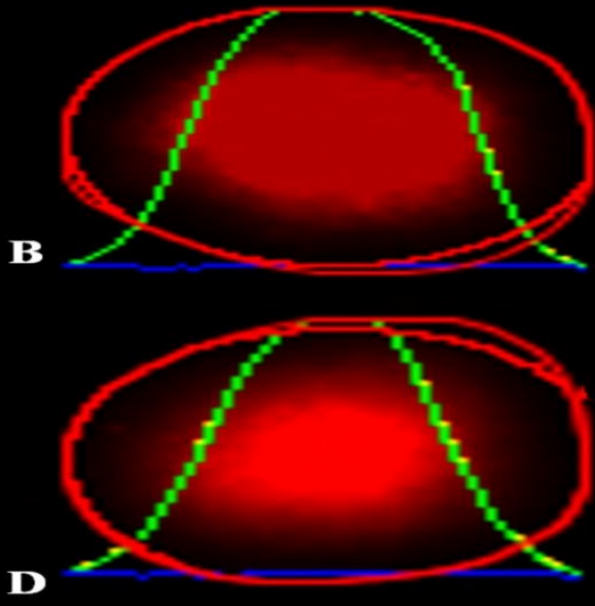


Table 1. Specification of the equipment used

\begin{tabular}{|c|c|}
\hline Parameters & Laser \\
\hline$\Lambda(\mathrm{mm})$ & 830 \\
\hline$\emptyset(\mathrm{m})$ & 0.8 \\
\hline $\mathrm{P}(\mathrm{M})$ & 0.04 \\
\hline $\mathrm{A}\left(\mathrm{cm}^{2}\right)$ & 0.93 \\
\hline $\mathrm{mode}$ & continuous \\
\hline
\end{tabular}

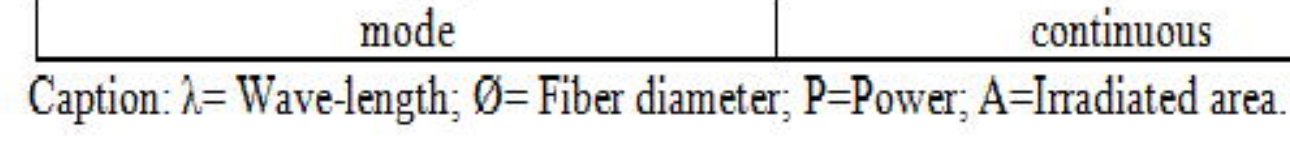




\section{Table 2 . Energy deposited in each experimental group
tale}

\begin{tabular}{|c|c|c|c|}
\hline Groups & Energy (I) & Energy Density $\left(J \mathrm{Im}^{2}\right)$ & Time $(\mathrm{s})$ \\
\hline G1 (control) & 0.0 & 0.0 & 0.0 \\
\hline G2 & 0.9 & 0.5 & 24,12 \\
\hline G3 & 2.7 & 1.5 & 73,5 \\
\hline G4 & 5.4 & 3.0 & 144,75 \\
\hline
\end{tabular}

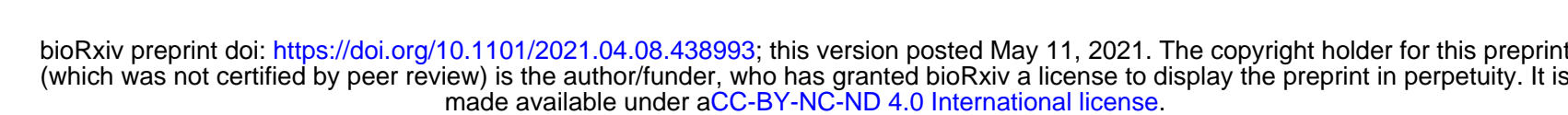

